\title{
KANDUNGAN FLAVONOID, TOTAL FENOL, DAN ANTIOKSIDAN SNACK BAR SORGUM SEBAGAI ALTERNATIF MAKANAN SELINGAN PENDERITA DIABETES MELLITUS TIPE 2
}

\author{
Linda Isdamayani, Binar Panunggal ${ }^{*}$ \\ Program Studi Ilmu Gizi Fakultas Kedokteran Universitas Diponegoro \\ J1.Dr.Sutomo No.18, Semarang, Telp (024) 8453708, Email : gizifk@ undip.ac.id
}

\begin{abstract}
Background: Sorghum (Sorghum bicolor) is local food containing antioxidant compounds like flavonoid and phenol total. Sorghum consumption was cooked as snack such as snack bar. Antioxidant compounds of sorghum could be useful for diabetes mellitus (DM) type 2 patients. DM type 2 was characterized by hyperglycemic increasing oxidative stress. Oxidative stress developed macro and microvascular complication.

Objective: To analyze flavonoid, phenol total, and antioxidant activity of snack bar from three varieties of sorghum. Method: This study was randomized single factor experimental design used sorghum variation (red, white, and brown). Flavonoid content was analyzed using allumunium chloride colorimetric, phenol total content was analyzed using Folin-Ciocalteu, and antioxidant activity was analyzed using DPPH.

Result: Flavonoid content, phenol total, and antioxidant activity of red sorghum snack bar was $0.015 \mathrm{mg} Q \mathrm{QE} / \mathrm{g}, 2.508$ $\mathrm{mg} \mathrm{GAE/g}$, and 53.431\%; white sorghum snack bar was $0.016 \mathrm{mg} \mathrm{QE/g,} 1.343 \mathrm{mg} \mathrm{GAE/g}$, and 38.987\%; and brown sorghum snack bar was $0.018 \mathrm{mg} Q E / g$, $4.679 \mathrm{mg} \mathrm{GAE} / \mathrm{g}$, and $64.431 \%$. There were differences in phenol total and antioxidant activity between three varieties of sorghum snack bar, however no differences in flavonoid content. There were differences in flavonoid content, phenol total, and antioxidant activity between sorghum grain and sorghum snack bar.

Conclusion: Brown sorghum snack bar has the highest flavonoid content, phenol total, and antioxidant activity than red and white sorghum snack bar. There are differences in flavonoid content, phenol total, and antioxidant activity between sorghum grain and sorghum snack bar. White sorghum snack bar is most preffered by panelis.
\end{abstract}

Keyword: snack bar, sorghum, flavonoid, phenol, antioxidant

\section{ABSTRAK}

Latar Belakang: Sorgum merupakan pangan lokal yang mengandung komponen antioksidan seperti favonoid dan total fenol. Konsumsi sorgum dapat diolah menjadi produk makanan selingan berupa snack bar. Kandungan antioksidan pada sorgum bermanfaat sebagai pangan sumber antioksidan bagi penderita diabetes mellitus (DM) tipe 2. Diabetes mellitus (DM) tipe 2 ditandai dengan hiperglikemia yang meningkatkan stres oksidatif. Stress oksidatif dapat berkembang menjadi komplikasi makro maupun mikrovaskuler.

Tujuan: Menganalisis kadar flavonoid, total fenol, dan aktivitas antioksidan pada snack bar dari tiga jenis sorgum. Metode: Penelitian ini merupakan penelitian rancangan acak lengkap satu faktor menggunakan variasi jenis sorgum (merah, putih, dan coklat). Analisis kadar flavonoid menggunakan allumunium chloride colorimetric, total fenol menggunakan Folin-Ciocalteu, dan aktivitas antioksidan dengan DPPH.

Hasil: Kadar flavonoid, total fenol, dan aktivitas antioksidan snack bar sorgum merah 0.015mg QE/g, $2.508 \mathrm{mg}$

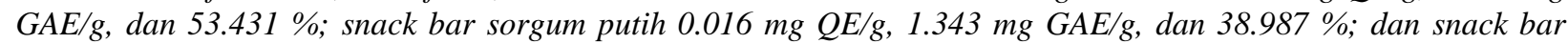
sorgum coklat $0.018 \mathrm{mg}$ QE/g, $4.679 \mathrm{mg}$ GAE/g, dan 64.431\%. Ada perbedaan kadar total fenol dan aktivitas antioksidan, namun tidak ada perbedaan kadar flavonoid pada snack bar sorgum. Ada perbedaan kandungan flavonoid, total fenol, dan aktivitas antioksidan antara biji sorgum dan snack bar sorgum.

Simpulan: Snack bar sorgum coklat mengandung flavonoid, total fenol, dan aktivitas antioksidan tertinggi dibanding snack bar sorgum merah dan putih. Ada perbedaan kandungan flavonoid, total fenol, dan aktivitas antioksidan antara biji sorgum dan snack bar sorgum. Snack bar sorgum putih paling disukai oleh panelis.

Kata kunci: snack bar, sorgum, flavonoid, fenol, antioksidan

\section{PENDAHULUAN}

Diabetes mellitus merupakan masalah kesehatan dengan jumlah penderita sebanyak 387 juta jiwa pada 2014 dan diprediksi akan meningkat menjadi 592 juta jiwa pada 2035. Penderita diabetes sebanyak $77 \%$ berasal dari negara dengan pendapatan rendah sampai menengah. ${ }^{1}$ Prevalensi Diabetes Mellitus (DM) di Indonesia pada 2007 sebesar $1,1 \%$ dan meningkat menjadi $2,1 \%$ pada 2013. Begitu juga dengan prevalensi DM di Jawa Tengah sebesar $1,3 \%$ pada 2007 menjadi $1,9 \%$ pada 2013. ${ }^{2}$ Hal tersebut menunjukkan bahwa kejadian diabetes mellitus akan terus mengalami peningkatan.

DM tipe 2 ditandai dengan hiperglikemia atau peningkatan glukosa darah yang disebabkan

${ }^{*}$ Penulis Penanggungjawab 
kelainan sekresi insulin, kerja insulin, maupun keduanya. $^{3}$ Hiperglikemia akan meningkatkan kejadian stres oksidatif pada penderita DM tipe $2 .{ }^{4}$ Stres oksidatif ditandai dengan peningkatan produksi radikal bebas dan penurunan aktivitas antioksidan dalam tubuh seperti superoxide dismutase (SOD), catalase (CAT), dan glutathione peroxidase. $^{5}$ Stres oksidatif ini akan memicu komplikasi mikrovaskuler seperti retinopati, neuropati, dan nefropati, serta komplikasi makrovaskuler seperti cardiovascular disease. ${ }^{3}$

Antioksidan dapat menghambat stres oksidatif pada penderita DM tipe 2. Antioksidan merupakan senyawa pemberi elektron yang menghambat reaksi oksidasi dengan cara mengikat radikal bebas dan molekul yang sangat reaktif sehingga mencegah kerusakan sel. Upaya pencegahan terhadap peningkatan stres oksidatif dan penurunan aktivitas antioksidan dalam tubuh yaitu mengasup makanan sumber antioksidan. ${ }^{6}$

Salah satu pangan lokal sumber antioksidan adalah sorgum. Sorgum (Sorghum bicolor) merupakan tanaman serealia yang mempunyai potensi besar untuk dibudidayakan di Indonesia dengan sifat tahan kekeringan, dapat ditanam pada lahan marginal, dan tahan hama. ${ }^{7}$ Sorgum memiliki aktivitas antioksidan sebesar $40,46 \% .{ }^{8}$ Sorgum menjadi pangan sumber antioksidan karena keberadaan komponen fenolik seperti asam fenolik, tanin terkondensasi, dan flavonoid. ${ }^{9}$ Total fenol pada biji sorgum berbagai warna yakni sorgum putih $4 \mathrm{mg}$ GAE/g, sorgum kuning $6.03 \mathrm{mg} \mathrm{GAE} / \mathrm{g}$, sorgum merah $6.97 \mathrm{mg} \mathrm{GAE} / \mathrm{g}$, dan sorgum coklat $10.01 \mathrm{mg}$ GAE$/ \mathrm{g}$. Kandungan flavonoid sorgum yakni 3,06 mg katekin ekuivalen/g. ${ }^{10,11}$ Flavonoid yang ditemukan pada sorgum dalam jumlah besar yaitu 3-deoksiantosianidin, flavon, dan flavanon. ${ }^{12}$ Komponen fenolik pada sorgum tersebut bermanfaat sebagai terapi diabetes mellitus. Pemberian ekstrak fenol sorgum Hwanggeumchal pada tikus diabetes yang diinduksi streptozotocin menurunkan serum glukosa secara signifikan. ${ }^{13}$

Berdasarkan kandungan antioksidan dan efek antihiperglikemik pada sorgum maka dapat digunakan sebagai bahan utama pembuatan snack bar sorgum sebagai makanan selingan penderita diabetes mellitus tipe 2. Makanan selingan berupa snack bar sorgum ini diharapkan dapat mencegah pembentukan radikal bebas dan penurunan aktivitas antioksidan tubuh, serta mengontrol gula darah pada penderita DM tipe 2. Pemilihan produk snackbar karena praktis dan memiliki umur simpan yang cukup baik. ${ }^{14}$ Oleh karena itu, dalam penelitian ini dilakukan pengujian terhadap kandungan flavonoid, total fenol, dan aktivitas antioksidan snack bar sorgum berbagai jenis sebagai makanan selingan untuk penderita DM tipe 2 .

\section{METODE}

Berdasarkan bidang keilmuan, penelitian yang dilakukan termasuk dalam bidang food production. Penelitian ini dilaksanakan di Laboratorium Ilmu Gizi dan Teknologi Pangan Universitas Muhammadiyah Semarang untuk menguji aktivitas antioksidan dan kadar total fenol serta di Laboratorium Pusat Antar Universitas Pangan dan Gizi Universitas Gadjah Mada untuk menguji kadar flavonoid. Penelitian ini dilaksanakan pada bulan Juli 2015.

Penelitian menggunakan rancangan acak lengkap satu faktor yaitu faktor variasi warna sorgum meliputi sorgum merah (S1), sorgum putih (S2), dan sorgum coklat (S3). Formulasi menyesuaikan kalori makanan selingan dari $10 \%$ Angka Kecukupan Gizi (AKG) serta kebutuhan karbohdrat, lemak, dan protein penderita DM tipe II menggunakan program software Nutrisurvey 2007. Perhitungan tersebut menghasilkan komposisi zat gizi yang diharapkan terdapat pada snack bar sebesar 204.76 kkal energi, 39.03 gram karbohidrat, 4.33 gram lemak, dan 5.03 gram protein dengan takaran saji snack bar sebesar 33 gram.

Penelitian dengan rancangan acak lengkap satu faktor yaitu tiga variasi jenis sorgum, meliputi sorgum merah, sorgum putih, dan sorgum coklat. Bahan baku terdiri dari sorgum merah dan sorgum putih yang diperoleh dari pasar Pracimantoro, Wonogiri, serta sorgum coklat yang diperoleh dari pasar Kendal, gula palem yang diperoleh dari toko bahan kue Fortuna, susu skim, dan minyak kelapa. Alat yang digunakan dalam pembuatan snack bar antara lain: timbangan digital, baskom, cetakan kue, pisau, sendok, spatula, dan panci. Proses pembuatan snack bar dimulai dari pencucian dan perendaman sorgum mentah, kemudian dibuat brondong sorgum dengan metode ekstrusi (puffing gun), gula palem dilelehkan dengan cara dipanaskan bersama minyak kelapa dan air, mencampurkan brondong sorgum dengan gula palem yang sudah meleleh serta susu skim, lalu dicetak serta dipadatkan pada cetakan kue lalu dipotong.

Data yang dikumpulkan pada penelitian ini meliputi kadar flavonoid menggunakan metode alumunium chloride colorimetric, total fenol menggunakan metode Folin-Ciocalteu, dan aktivitas antioksidan dengan metode DPPH. ${ }^{15}$ Tingkat penerimaan produk menggunakan uji kesukaan dengan 4 skala, yakni $1=$ sangat tidak suka, $2=$ tidak suka, $3=$ suka, $4=$ =sangat suka oleh 25 panelis agak terlatih yaitu mahasiswa Program 
Studi Ilmu Gizi Fakultas Kedokteran Universitas Diponegoro yang dilakukan satu kali uji kesukaan.

\section{HASIL}

\section{Kandungan Flavonoid, Total Fenol, dan} Aktivitas Antioksidan

Hasil uji kadar flavonoid, total fenol, dan aktivitas antioksidan berbagai jenis biji sorgum menunjukkan sorgum coklat memiliki kadar flavonoid, total fenol, dan aktivitas antioksidan tertinggi jika dibandingkan dengan biji sorgum merah dan sorgum putih yakni $0.026 \mathrm{mg} \mathrm{QE} / \mathrm{g}$, $12.014 \mathrm{mg} \mathrm{GAE} / \mathrm{g}$, dan $95.377 \%$. Kadar flavonoid terendah pada biji sorgum merah yakni $0.020 \mathrm{mg}$ QE/g. Aktivitas antioksidan dan total fenol terendah pada biji sorgum putih yakni $81.643 \%$ dan $9.081 \mathrm{mg}$ $\mathrm{GAE} / \mathrm{g}$.

Hasil uji kadar flavonoid, total fenol, dan aktivitas antioksidan berbagai jenis biji sorgum dapat dilihat pada tabel 1 berikut ini.

Tabel 1.Hasil uji kadar flavonoid, total fenol, dan aktivitas antioksidan biji sorgum

\begin{tabular}{cccc}
\hline Sorgum & $\begin{array}{c}\text { Flavonoid } \\
(\mathbf{m g ~ Q E} / \mathbf{g})\end{array}$ & $\begin{array}{c}\text { Total fenol } \\
(\mathbf{m g ~ G A E} / \mathbf{g})\end{array}$ & $\begin{array}{c}\text { Aktivitas } \\
\text { antioksidan }(\%)\end{array}$ \\
\hline Merah & $0.020 \pm 0.001$ & $10.067 \pm 0.076^{\mathrm{b}}$ & $89.392 \pm 2.560$ \\
Putih & $0.023 \pm 0.001$ & $9.081 \pm 0.440^{\mathrm{b}}$ & $81.643 \pm 1.829^{\mathrm{b}}$ \\
Coklat & $0.026 \pm 0.002$ & $12.014 \pm 0.126^{\mathrm{a}}$ & $95.378 \pm 1.636^{\mathrm{a}}$ \\
\hline
\end{tabular}

Keterangan: angka yang diikuti huruf superscript berbeda menunjukkan beda nyata

Kadar flavonoid, total fenol, dan aktivitas total fenol, dan aktivitas antioksidan snack bar antioksidan snack bar sorgum yang tertinggi adalah sorgum dapat dilihat pada tabel 2 berikut ini. snack bar sorgum coklat. Hasil uji kadar flavonoid,

Tabel 2. Hasil uji kadar flavonoid, total fenol, dan aktivitas antioksidan snack bar sorgum

\begin{tabular}{cccc}
\hline Snack bar Sorgum & $\begin{array}{c}\text { Flavonoid } \\
(\mathbf{m g ~ Q E} / \mathbf{g})\end{array}$ & $\begin{array}{c}\text { Total fenol } \\
(\mathbf{m g ~ G A E} / \mathbf{g})\end{array}$ & $\begin{array}{c}\text { Aktivitas } \\
\text { antioksidan(\%) }\end{array}$ \\
\hline Merah & $0.015 \pm 0.003$ & $2.508 \pm 0.316^{\mathrm{b}}$ & $53.431 \pm 1.075^{\mathrm{b}}$ \\
Putih & $0.016 \pm 0.003$ & $1.343 \pm 0.140^{\mathrm{c}}$ & $38.987 \pm 0.465^{\mathrm{c}}$ \\
Coklat & $0.018 \pm 0.002$ & $4.679 \pm 0.268^{\mathrm{a}}$ & $64.431 \pm 0.230^{\mathrm{a}}$ \\
\hline
\end{tabular}

Keterangan: angka yang diikuti huruf superscript $(\mathrm{a}, \mathrm{b}, \mathrm{c})$ berbeda menunjukkan beda nyata

Data snack bar sorgum merah, putih, dan coklat berdistribusi normal setelah diuji normalitas sehingga analisis menggunakan One Way Anova. Tidak terdapat perbedaan kandungan flavonoid pada snack bar sorgum merah, putih, dan coklat $(\mathrm{p}=0.455)$. Ada perbedaan total fenol $(\mathrm{p}=0.000)$ dan aktivitas antioksidan $(\mathrm{p}=0.000)$ pada snack bar sorgum merah, putih, dan coklat.

Tabel 3. $\Delta$ mean kadar flavonoid, total fenol, dan aktivitas antioksidan biji sorgum dan snack bar sorgum

\begin{tabular}{cccc}
\hline & $\begin{array}{c}\text { Flavonoid } \\
(\mathbf{m g ~ Q E} / \mathbf{g})\end{array}$ & $\begin{array}{c}\text { Total fenol } \\
(\mathbf{m g ~ G A E} / \mathbf{g})\end{array}$ & $\begin{array}{c}\text { Aktivitas } \\
\text { antioksidan(\%) }\end{array}$ \\
\hline$\Delta$ sorgum dan snack bar & $-0.005 \pm 0.003$ & $-7.559 \pm 0.316$ & $-35.961 \pm 1.075^{\mathrm{b}}$ \\
$\begin{array}{c}\text { sorgum merah } \\
\Delta \text { sorgum dan snack } \text { bar }\end{array}$ & $-0.007 \pm 0.003$ & $-7.738 \pm 0.140$ & $-42.656 \pm 0.465^{\mathrm{a}}$ \\
$\begin{array}{c}\text { sorgum putih } \\
\Delta \text { sorgum dan snack } \text { bar } \\
\quad \text { sorgum coklat }\end{array}$ & $-0.008 \pm 0.002$ & $-7.335 \pm 0.268$ & $-30.947 \pm 0.230^{\mathrm{c}}$ \\
\hline
\end{tabular}

Keterangan: angka yang diikuti huruf superscript $(\mathrm{a}, \mathrm{b}, \mathrm{c})$ berbeda menunjukkan beda nyata

Terdapat penurunan kandungan flavonoid, total fenol, dan aktivitas antioksidan dari sorgum mentah menjadi produk snack bar. Hal ini dapat dilihat pada diagram 1, 2, dan 3 berikut. 


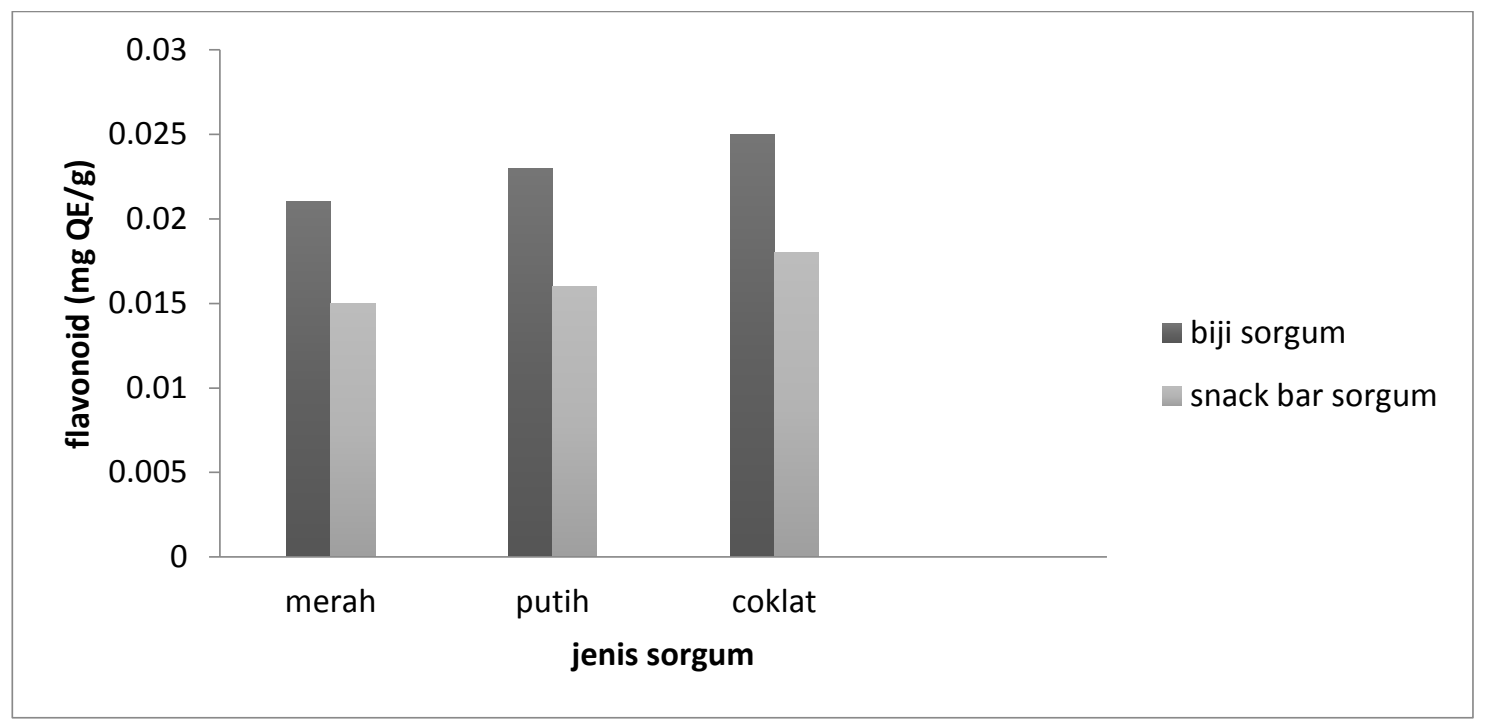

Gambar 1. Kandungan Flavonoid Biji Sorgum dan Snack bar Sorgum berbagai jenis

Kandungan flavonoid sorgum yang telah penurunan signifikan dari biji mentah sorgum diolah menjadi snack bar sorgum menunjukkan menjadi produk snack bar sorgum $(\mathrm{p}=0.009)$.

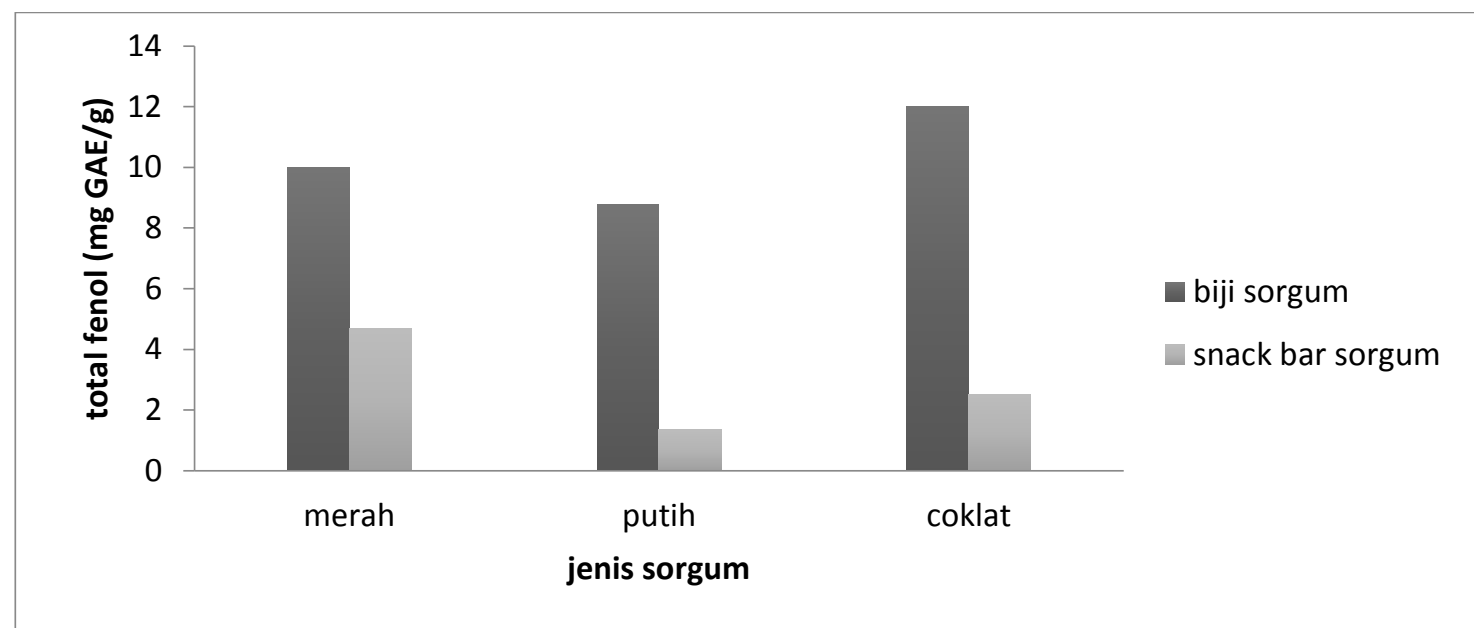

Gambar 2. Kandungan Total Fenol Biji Sorgum dan Snack bar sorgum berbagai jenis

Total fenol sorgum yang telah diolah signifikan dari biji mentah sorgum menjadi produk menjadi snack bar sorgum menunjukkan penurunan snack bar sorgum $(\mathrm{p}=0.025)$.

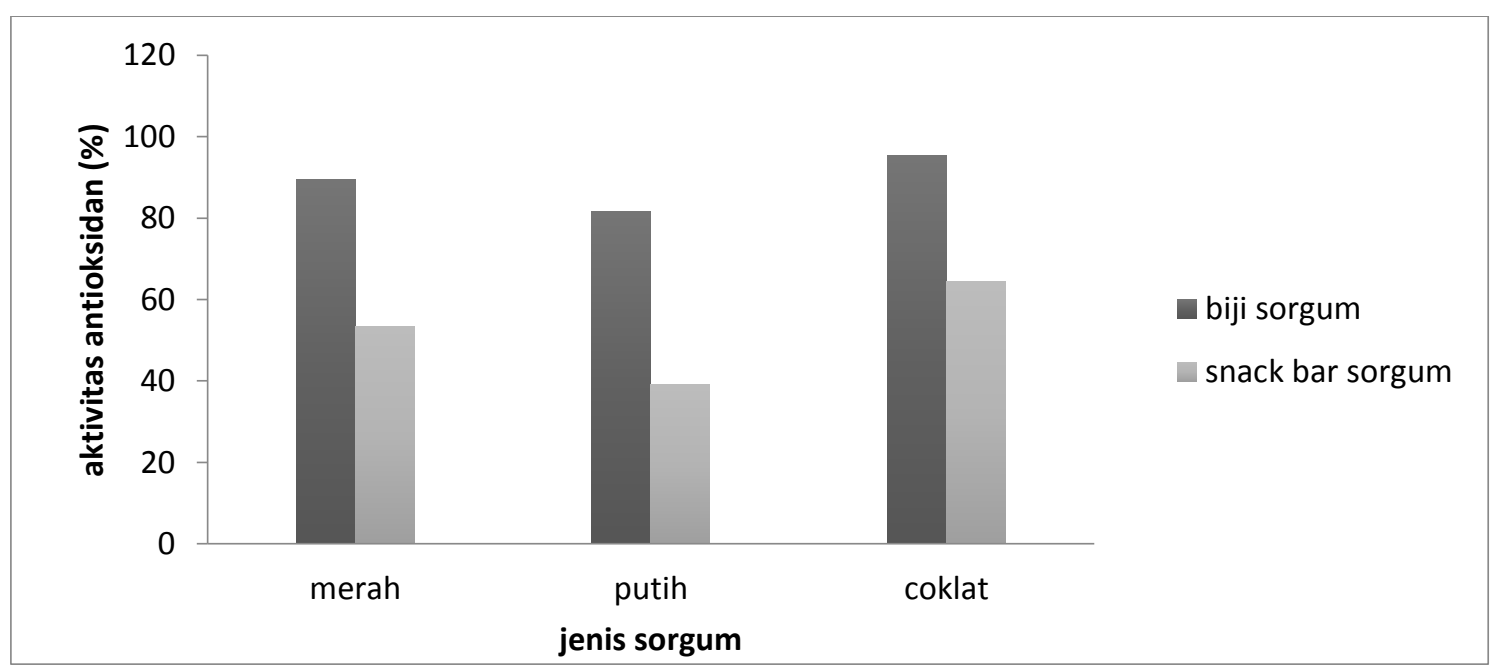

Gambar 3. Aktivitas Antioksidan Sorgum dan Snack bar sorgum berbagai jenis 
Tabel 4. Hasil Uji Kesukaan Snack Bar Sorgum

\begin{tabular}{|c|c|c|c|c|c|c|c|c|}
\hline \multirow{2}{*}{$\begin{array}{l}\text { Snack } \\
\text { bar } \\
\text { sorgum }\end{array}$} & \multicolumn{2}{|c|}{ Warna } & \multicolumn{2}{|c|}{ Aroma } & \multirow{2}{*}{$\begin{array}{c}\text { Tekstur } \\
\text { Rerata }\end{array}$} & \multicolumn{3}{|c|}{ Rasa } \\
\hline & Rerata & Ket & Rerata & Ket & & Ket & Rerata & Ket \\
\hline Merah & $2,56 \pm 0,507$ & suka & $2,96 \pm 0,539$ & suka & $2,48 \pm 0,653$ & $\begin{array}{l}\text { tidak } \\
\text { suka }\end{array}$ & $2,84 \pm 0,624$ & suka \\
\hline Putih & $3,16 \pm 0,624$ & suka & $2,80 \pm 0,816$ & suka & $2,68 \pm 0,627$ & suka & $3,12 \pm 0,440$ & suka \\
\hline Coklat & $2,12 \pm 0,726$ & $\begin{array}{l}\text { tidak } \\
\text { suka }\end{array}$ & $2,80 \pm 0,957$ & suka & $2,48 \pm 0,714$ & $\begin{array}{l}\text { tidak } \\
\text { suka }\end{array}$ & $2,76 \pm 0,879$ & suka \\
\hline
\end{tabular}

Berdasarkan keempat parameter uji kesukaan, snack bar sorgum putih paling disukai panelis. Snack bar sorgum merah kurang disukai dari segi tekstur dan sorgum coklat kurang disukai dari segi rasa dan tekstur.

\section{PEMBAHASAN}

\section{Kadar Flavonoid}

Snack bar sorgum coklat mengandung flavonoid tertinggi. Berdasarkan analisis uji statistik, kadar flavonoid snack bar merah, putih, dan coklat tidak menunjukkan perbedaan $(\mathrm{p}=0.455)$. Tidak adanya perbedaan flavonoid karena masingmasing jenis sorgum memiliki kandungan kelas flavonoid yang berbeda-beda. Tiga kelas besar flavonoid tersebut yaitu 3-deoksiantosianidin, flavon, dan flavanon. Ketiga kelas flavonoid tersebut menentukan besarnya total flavonoid pada sorgum. Penelitian oleh Taleon et al menunjukkan tidak adanya hubungan antara warna biji dengan kandungan flavonoid. Warna biji sorgum yang semakin rendah tingkat kecerahannya $\left(\mathrm{L}^{*}\right)$ atau semakin gelap warnanya tidak berarti semakin tinggi kandungan flavonoidnya. ${ }^{16,17}$

Pengolahan sorgum menjadi produk snack bar ini menurunkan kandungan flavonoidnya. Hasil uji statistik menunjukkan perbedaan antara sorgum mentah dan produk snack bar sorgum $(\mathrm{p}=0.009)$. Tanin yang terkandung pada sorgum menimbulkan rasa pahit pada produk olahan sorgum. Cara yang dapat dilakukan untuk mengurangi rasa pahit pada produk olahan sorgum yaitu dengan merendam biji sorgum. ${ }^{18} \mathrm{Hal}$ ini diterapkan pada pengolahan snack bar ini dengan harapan produk ini dapat diterima dari segi rasanya. Akan tetapi, komponen fenolik lainnya seperti flavonoid juga mengalami penurunan. Komponen flavonoid sorgum seperti luteolin, apigenin, kampferol, hypersoid, quercetin, catechin, christin, dan naringenin menunjukkan penurunan setelah perendaman. Penurunan total fenol, flavonoid, dan tanin setelah perendaman disebabkan oleh larutnya komponen fenol ke dalam air rendaman. ${ }^{19}$
Selain proses perendaman, pengolahan sorgum menjadi produk brondong sorgum (bahan utama snack bar) menyebabkan penurunan komponen antioksidan. Biji sorgum yang diolah menjadi brondong sorgum dengan alat conventional popper menunjukkan kandungan antioksidan yang tetap atau tidak mengalami penurunan. ${ }^{20}$ Namun pada penelitian snack bar sorgum ini, proses pengolahan biji sorgum menjadi brondong menggunakan metode ekstrusi (puffing gun). Metode ekstruksi ini menimbulkan penurunan komponen fenolik. Pemasakan dengan metode ekstrusi menurunkan total fenol yang dipengaruhi oleh kelembapan selama proses ekstrusi. Kelembapan yang tinggi dapat meningkatkan polimerisasi fenolik yang menyebabkan turunnya komponen fenolik produk ekstrusi dibanding biji mentahnya. ${ }^{21}$

Rata-rata asupan flavonoid sebesar $14.5 \mathrm{mg}$ pada laki-laki dan $20.4 \mathrm{mg}$ pada perempuan per hari. Produk snack bar sorgum coklat yang memiliki kandungan flavonoid tertinggi dibanding snack bar sorgum merah dan putih memenuhi $0.04 \%$ flavonoid untuk laki-laki per sajian snack bar (33 gram). Berdasarkan rata-rata asupan flavonoid pada perempuan, Snack bar sorgum coklat memenuhi $0.03 \%$ flavonoid per sajian snack bar. ${ }^{22}$

Flavonoid berperan sebagai antioksidan sekunder pada penderita DM tipe 2.

Penderita DM tipe 2 mengalami hiperglikemia yang memicu stress oksidatif. Stres oksidatif ini menyebabkan peningkatan radikal bebas dan penekanan antioksidan enzimatik. Akibatnya tubuh perlu mengasup antioksidan nonenzimatik yang diperoleh dari sumber pangan. Antioksidan yang diasup dari luar ini fungsinya sebagai antioksidan sekunder. Antioksidan sekunder bekerja dengan cara memotong reaksi oksidasi beranta radikal bebas dan menangkap radikal bebas. ${ }^{5,6}$

Pengaruh pemberian flavonoid dalam mencegah stress oksidatif pada tikus diabetes yang diinduksi streptozotocin menunjukkan pemberian quercetin (salah satu flavonoid) pada dosis 15 
$\mathrm{mg} / \mathrm{kg}$ menyebabkan penurunan yang signifikan terhadap peningkatan malondialdehid (MDA) dan nitrit oxide (NO) serta ada peningkatan aktivitas antioksidan enzimatik. Pemberian quercetin memberikan efek protektif terhadap DM melalui penurunan peroksidasi lipid dan produksi NO, serta peningkatan aktivitas antioksidan enzimatik. ${ }^{23}$

\section{Kadar Total Fenol}

Snack bar sorgum coklat memiliki kadar total fenol tertinggi yakni $4.679 \mathrm{mg}$ GAE/g, sedangkan kadar total fenol terendah terdapat pada snack bar dari sorgum putih yaitu $1.343 \mathrm{mg} \mathrm{GAE} / \mathrm{g}$. Terdapat perbedaan kadar total fenol snack bar pada ketiga jenis sorgum. Total fenol merupakan komponen fitokimia biji sorgum yang terdapat pada bagian perikarp dan testa. Warna perikarp dan pigmen testa dalam biji sorgum ini yang menentukan ada tidaknya komponen fenol. ${ }^{10}$ Sorgum dan snack bar sorgum coklat dalam hasil penelitian ini memiliki kandungan total fenol tertinggi, hal ini dapat disebabkan oleh adanya pigmen testa dalam biji sorgumnya. Pigmen testa merupakan penanda ada tidaknya tanin terkondensasi (proantosianidin) dalam biji sorgum. Penelitian yang dilakukan oleh L. Dykes et al, terdapat hubungan yang kuat antara total fenol dan tanin terkondensasi. Tingginya total fenol dalam sorgum karena kontribusi dari tanin terkondensasi. ${ }^{24}$

Pengolahan sorgum menjadi snack bar menunjukkan penurunan pada kadar total fenolnya $(\mathrm{p}=0.025)$. Pengolahan sorgum menjadi produk brondong tidak menurunkan total fenolnya. ${ }^{20}$ Namun, pada penelitian ini melalui proses perendaman biji sorgum untuk menghilangkan rasa pahit pada produk olahan sorgum. ${ }^{18}$

Perendaman tidak hanya menurunkan kandungan tanin dalam biji sorgum namun juga menyebabkan penurunan kandungan fenolik lainnya yakni asam fenolik yang terdiri dari ferulic acid, protocateuchic acid, p-coumaric acid, phydroxybezoic acid, vanillic acid, galic acid, caffeic acid, syringic acid, dan cinnamic acid dan flavonoid. Komponen fenolik sorgum dapat larut dalam air rendaman sehingga menurunkan kandungan total fenolnya. ${ }^{19}$ Penelitian yang dilakukan oleh $\mathrm{Wu} \mathrm{L}$ et al menunjukkan adanya penurunan kadar total fenol pada biji sorgum yang dipanggang sebesar $4.33 \mathrm{mg}$ GAE/g dari $8.92 \mathrm{mg}$ GAE/g total fenol pada biji mentahnya, hal ini dikarenakan biji sorgum tersebut melalui proses perendaman terlebih dahulu. ${ }^{8}$ Selain itu, metode ekstrusi untuk membuat brondong sorgum pada penelitian ini ternyata menyebabkan penurunan total fenol dalam produk olahan sorgum. ${ }^{21}$
Rata-rata asupan fenolik sebesar $6 \mathrm{mg} / \mathrm{hari}$ untuk laki-laki dan $15.1 \mathrm{mg} /$ hari untuk perempuan. Snack bar sorgum coklat memenuhi sebesar $25.73 \%$ fenolik untuk laki-laki per sajian snack bar (33 gram). Kebutuhan fenolik pada perempuan terpenuhi $10.23 \%$ fenolik per sajian snack bar sorgum coklat. $^{22}$

Peran fenol sebagai terapi DM tipe 2 yaitu sebagai antioksidan sekunder. Selain itu, komponen fenolik dalam sorgum berfungsi menurunkan kadar gula darah. Pemberian ekstrak fenolik sorgum dosis $0.25 \mathrm{~g} / \mathrm{kg}$ pada tikus diabetes yang diinduksi streptozotocin menunjukkan aktivitas hipoglikemik dan secara signifikan menurunkan serum glukosa. ${ }^{13}$ Selain itu, pada penelitian lain menunjukkan penurunan gula darah pada tikus diabetes setelah pemberian ekstrak sorgum 0.4 dan $0.6 \mathrm{~g} / \mathrm{kg}$ berat badan. Ekstrak sorgum menurunkan kadar glukosa darah dengan cara menghambat glukoneogenesis. Glukoneogenesis dihambat dengan cara penekanan enzim phospohoenolpyruvate carboxykinase (PEPCK) melalui peningkatan adenosine monophospate activated protein kinase (AMPK) di hati. ${ }^{25}$

\section{Aktivitas Antioksidan}

Aktivitas antioksidan pada ketiga jenis snack bar yaitu snack bar sorgum merah, putih, dan coklat menunjukkan perbedaan $(\mathrm{p}=0.000)$. Aktivitas antioksidan tertinggi terdapat pada snack bar sorgum coklat. Warna coklat pada sogum menunjukkan adanya kandungan proantosianidin (tanin terkondensasi) yang tinggi. Proantosianidin merupakan sumber antioksidan terbaik. ${ }^{10}$

Pengolahan sorgum menjadi snack bar menunjukkan penurunan yang signifikan pada aktivitas antioksidan $(\mathrm{p}=0.005)$. Sorgum yang diolah menjadi brondong (bahan utama snack bar sorgum) menggunakan alat conventional popper menunjukkan penurunan aktivitas antioksidannya. Namun, pada penelitian ini metode untuk membuat brondong sorgum yaitu menggunakan metode ekstrusi. Metode ekstrusi menurunkan aktivitas antioksidan produk olahan sorgum dibanding biji mentahnya.

Selain itu, sebelum pengolahan menjadi produk snack bar, sorgum melalui proses perendaman untuk mengurangi kandungan tanin dalam biji yang menyebabkan rasa pahit pada produk pangan. Perendaman biji sorgum dapat menyebabkan penurunan aktivitas antioksidan setelah produk diolah. Sorgum yang direndam terlebih dahulu sebelum diolah secara dipanggang menunjukkan aktivitas antioksidan yang lebih rendah yakni $25.66 \%$ dibandingkan sorgum mentahnya yakni $40.46 \%{ }^{8}$ 
Penderita DM tipe 2 mengalami stress oksidatif yang ditandai dengan peningkatan radikal bebas dan penurunan fungsi antioksidan primer (antioksidan endogen) seperti superoxide dismutase (SOD), catalase (CAT), dan glutathione peroxidase. Oleh karenanya, penderita diabetes mellitus tipe 2 perlu mengasup pangan sumber antioksidan (antioksidan eksogen) sebagai antioksidan sekunder yang membantu kerja antioksidan primer. ${ }^{5,6} \mathrm{Di}$ dalam tubuh, fungsi antioksidan makanan dapat diamati melalui biomarker plasma antioxidant capacity (PAC). PAC meliputi aktivitas antioksidan dari makanan dan antioksidan endogen. PAC menunjukkan biomarker penyerapan antioksidan makanan dalam tubuh. Apabila antioksidan makanan terserap, PAC akan meningkat. ${ }^{26}$

\section{Tingkat Penerimaan Snack Bar Sorgum}

Snack bar sorgum putih paling disukai panelis dari segi warna, rasa, tekstur, dan aroma. Namun, berdasarkan uji statistik tidak ada perbedaan berdasarkan parameter rasa, tekstur, dan aroma. Hal ini disebabkan oleh bahan utama snack bar yaitu sorgum yang umumnya sama hanya berbeda jenis dan warna saja. Parameter warna menunjukkan perbedaan pada snack bar sorgum merah dengan putih dan snack bar sorgum coklat dengan putih.

Warna snack bar sorgum merah, putih, dan coklat rata-rata sama karena snack bar yang dilapisi oleh karamel gula palem sebagai pengikat antar brondong sorgum agar terbentuk snack bar. Warna snack bar sorgum merah dan coklat memiliki warna yang lebih gelap dibandingkan snack bar sorgum putih. Hal ini dapat disebabkan oleh kandungan 3deoksiantosianidin yang tinggi pada sorgum merah dan proantosianidin pada sorgum coklat yang menimbulkan warna gelap pada perikarp biji. ${ }^{10}$ Perpaduan warna brondong sorgum putih dengan karamel gula palem lebih menarik dan disukai jika dibandingkan dengan snack bar sorgum merah dan coklat.

Penilaian mengenai aroma snack bar, panelis menyatakan bahwa ketiga snack bar memiliki aroma yang sama. Aromanya harum yang berasal dari karamel gula palem. Gula karamel sering digunakan sebagai bahan pemberi cita rasa makanan yang memiliki aroma harum yang disukai panelis. ${ }^{27}$

Penilaian mengenai tekstur, snack bar sorgum merah dan coklat kurang disukai panelis karena kurang renyah. Tekstur yang lebih disukai adalah snack bar sorgum putih. Kerenyahan snack bar sorgum dapat dipengaruhi oleh pengembangan sorgum saat dibrondong. Pengembangan sorgum saat dibrondong dipengaruhi oleh kadar amilopektin dan amilosa. Semakin tinggi kandungan amilopektin, brondong sorgum yang dihasilkan lebih mekar atau mengembang. ${ }^{27}$

Rasa snack bar sorgum yang paling disukai panelis adalah snack bar sorgum putih. Hasil uji statistik menunjukkan rasa ketiga snack bar tidak ada perbedaan atau disukai panelis. Namun, rasa snack bar sorgum coklat kurang disukai panelis karena rasa pahit setelah dimakan. Rasa pahit pada snack bar sorgum coklat dapat dipengaruhi oleh adanya kandungan proantosianidin (tanin terkondensasi). Proantosianidin terdapat pada biji sorgum yang memiliki pigmen testa dan warna gelap pada perikarp biji sorgum dapat menjadi indikator keberadaan proantosianidin. ${ }^{10}$ Sorgum coklat memiliki warna perikarp lebih gelap dibanding sorgum merah dan putih mengandung tinggi proantosianidin yang berkontribusi pada rasa pahit snack bar sorgum coklat.

\section{SIMPULAN}

Kadar flavonoid, total fenol, dan aktivitas antioksidan tertinggi terdapat pada snack bar sorgum coklat yakni $0.018 \mathrm{mg}$ QE/g, $4.679 \mathrm{mg}$ GAE/g, dan $64.431 \%$. Pengolahan sorgum menjadi produk snack bar menyebabkan penurunan kandungan flavonoid, total fenol, dan aktivitas antioksidan.

\section{SARAN}

Produk snack bar yang paling disukai dari segi rasa, warna, aroma, dan tekstur adalah snack bar sorgum putih. Namun, snack bar yang tinggi kandungan antioksidannya adalah snack bar sorgum coklat. Konsumsi snack bar sorgum coklat per harinya mampu memenuhi kebutuhan flavonoid sebesar $0.03 \%$ dan fenol sebesar $10.23 \%$ per sajian snack bar (33 gram).

\section{DAFTAR PUSTAKA}

1. International Diabetes Federation. IDF Diabetes Atlas 2014 Update [Internet]. 2014 [cited 2015 May 6]. Available from: http://www.idf.org/diabetesatlas/update-2014

2. Badan Penelitian dan Pengembangan Kesehatan Kementerian Kesehatan RI Tahun 2013. Riset Kesehatan Dasar (Riskesdas) 2013.

3. American Diabetes Association. Standards of Medical Care in Diabetes 2010. Diab Care. 2010; 33.

4. Roth SL. Diseases of the endocrine system. In Nelms M, Sucher KP, Lace K, Roth SL. Nutrition therapy and phatophysiology. $2^{\text {nd }}$ ed. USA: Wadsworth Cengage Learning. 2007. p.471-519. 
5. Maritim AC, Sanders RA, Watkins JB. Diabetes, oxidative stress, and antioxidants: a review. J Biochem Molecular Toxicology. 2003; 17 (1): 24 38.

6. Winarsi H. Antioksidan alami dan radikal bebas. 2007. Yogyakarta: Kanisius. P.77-81

7. Sirappa MP. Prospek pengembangan sorgum di indonesia sebagai komoditas alternatif untuk pangan, pakan, dan industri. Jurnal Litbang Pertanian. 2003; 22(4): 133-140.

8. Wu L, Zhaohui H, Peiyou Q, Guixing R. Effects of processing on phytochemical profiles and biological activities for production of sorghum tea. Food Research International. 2013; 53(2): 678-685.

9. Dykes L, Rooney LW. Sorghum and millet phenols and antioxidants. Journal of cereal science. 2006; 44(3) : 236-251.

10. Rhodes DH, Hoffmann L, Rooney WL, Ramu P, Morris GP, Kresovich S. Genome-wide association study of grain polyphenol concentrations in global sorghum [Sorghum bicolor (L.) Moench] germplasm. J. Agric. Food Chem. 2014; 62: 1091627.

11. Moraes EA, Marineli RS, Lenquist SA, Steel CJ, Menezes CB, Queiros VA et al. Sorgum flour fractions: correlations among polysaccharides, phenolic compounds, antioxidant activity and glycemic index. Journal food chemistry. 2015; 180: 116-123.

12. Dykes L, Peterson GC, Rooney WL, Rooney LW. Flavonoid composition of lemon yellow sorghum genotypes. Food Chemistry. 2011; 128(1): 173-179.

13. Chung IM, Kim EH, Yeo MA, Kim SJ, Seo MC, Moon HI. Antidiabetic effects of three Korean sorghum phenolic extracts in normal and streptozotocin-induced diabetic rats. 2011; 44(1): 127-132.

14. Wibowo OA. Optimasi formulasi pembuatan snack bar kacang merah-apel malang dengan menggunakan program linier [skripsi]. Bandung: Universitas Pasundan. 2010.

15. Polumahanthi S, Nallamilli SM. Comparative studies on raw and cooked extracts of sorghum cultivas for their bio-active constituents. International Journal of advanced research. 2014; 2(2): 804-813.

16. Taleon V, Dykes L, Rooney WL, Rooney LW. Effect of genotype and environment on flavonoid concentration and profile of black sorghum grains. Journal of Cereal Science. 2012; 56 (2): 470-475.

17. Taleon V, Dykes L, Rooney WL, Rooney LW. Environmental effect on flavonoid concentrations and profiles of red and lemon-yellow sorghum grains. Journal of Food Composition and Analysis. 2014; 34 (2): 178-185.

18. Suarni. Potensi Sorgum sebagai Bahan Pangan Fungsional. IPTEK Tanaman Pangan. 2012; 7 (1): 58-67.

19. Afify AEMR, El-Beltagi HS, El-Salam SMA, Omran AA. Biochemical changes in phenols, flavonoids, tannins, vitamin E, -carotene and antioxidant activity during soaking of three white sorghum. Asian Pacific Journal of Tropical Biomedicine. 2012; 3(2): 203-209.

20. Cardoso LM, Montini TA, Pinheiro SS, PinheiroSant'Ana HM, Martino HSD, Moreira AVB. Effects of processing with dry heat and wet heat on the antioxidant profile of sorghum. 2013; 152: 210 217.

21. Dlamini NR, Taylor JRN, Rooney LW. The effect of sorghum type and processing on the antioxidant properties of African sorghum-based foods. Food Chemistry. 2007; 4(105): 1412-1219.

22. Murphy MM, Barraj LM, Herman D, Bi X. Phytonutrient intake by adults in the United States in relation to fruit and vegetables consumption. $\mathrm{J}$ Acad Nutr Diet. 2012; 112: 1626-35

23. Coskun O, Kanter M, Korkmaz A, Oter S. Quercetin, a flavonoid antioxidant, prevents and protects streptozotocin-induce oxidative stress and $\beta$-cell damage in rat pancreas. Pharmacological Research. 2005; 51 (2): 117-123.

24. Dykes L, Rooney WL, Rooney LW. Evaluation of phenolics and antioxidant activity of black sorghum hybrids. Journal of Cereal Science. 2013; 58: 278283.

25. Kim J, Park Y. Anti-diabetic effect of sorghum extract on hepatic gluconeogenesis of streptozotocin-induced diabetic rats. Nutrition and Metabolism. 2012; 106 (9): 1-7.

26. Fernandez-Panchon MS, Villano D, Troncoso AM, Garcia-Parrilla MC. Antioxidant Activity of Phenolic Compounds: From In Vitro Results to In Vivo Evidence. Critical Reviews in Food Science and Nutrition. 2008; 48: 649-671.

27. Winarno FG. Kimia Pangan dan Gizi. Jakarta: Gramedia.2004.p. 27-32,41. 